\title{
The Effectiveness of P.O.S.S.E Strategy on Improving Reading Comprehension of the EFL University Students
}

\author{
Ali Sabah Jameel \\ University of Anbar, Faculty of Education For Humanities, English Language Department
}

\begin{abstract}
The present study aims to reveal the effectiveness of using P.O.S.S.E Strategy in improving reading comprehension for the second grade university students in Iraq. To achieve this aim, the researcher conducted an action research. The total number of the participants is 69 (Male and Female Students). An observation checklist, Pre-post tests were used to collect the quantitative and qualitative data of the study. The results showed that there was positive statistical significance difference on the students' scores on the posttest due to the treatment. Also, there was an observed improvement on students' reading comprehension.
\end{abstract}

Keywords- P.O.S.S.E Strategy, Reading comprehension, EFL University Students.

\section{INTRODUCTION}

Scholars "have been concerned with the process of reading for thousands of years"; and although extensive researches have been conducted, the teachers and the specialists still lack a "clear stated, empirical supported, and theoretical unassailable definition of reading comprehension" (Bernhardt, 1991:5).

In the present study, the researcher found that the most appropriate definition close to the aim of the study is the one which presented by Hudson. Hudson (2007:28) articulated assumptions that can help the teachers to make sense of competing models. The first of these is "reading is meaning based". Second, we should assume that "the active reader provides a lot of the information necessary to comprehend any text".

Reading classes, as well as language and literacy classes that organize reading as a prime component, may utilize intensive or extensive approaches or mixing of the two to reach the ultimate goal which is the comprehensive reading, to enable the learners and the readers to comprehend the text (Hedgcock, and Ferris 2009: 160161).

The large lump of second or foreign language reading textbooks, as well teacher's guide book, endorse an intensive approach to comprehend the text, and only sometimes use extensive, self-selected reading, perhaps as an optional supplement to the reading syllabus (Aebersold and field, 1997).

The procedures of implementing P.O.S.S.E Strategy are based on three stages (Pre-Reading, Reading, and post Reading) presented by framework utilized by California state University Expository reading and Writing task force (2008). This framework outline crucial academic reading skills and strategies for intensive reading (Hedgcock, and Ferris, 2009: 162).

\subsection{Statement of the Problem}

From the researcher experience in teaching at English department, it is noted that EFL students lack the ability of comprehending any new (unseen) text, which is the major aim of reading in the foreign language instruction. EFL students at English department must study "comprehension Subject" in the first and second grades. The comprehension subject aims to enable the EFL students to comprehend a text, maximize vocabularies, stated the main idea of each paragraph, and to present a summary of a given topic, because comprehending a new topic is not easy for the EFL students.

The researcher observes many factors that affect negatively students comprehending of a given the text.

The first factor is related to the reading strategies. EFL students lack reading strategies. The second factor is related to the EFL instructor who use translation strategy in teaching reading skill, the majority of EFL instructors at English department do not use pre-reading, reading, Post-reading activities due to the huge number of the students and short period of the course.

The third factor is related to the students' lack of active participation inside the classroom: to ask question, to derive the meaning of new words, and motivation to comprehend the new topic. The fourth factor is related to students' reading comprehension mechanisms such as lack of stock vocabularies, finding the main ideas, and the supported ideas, stated and unstated details.

To overcame these factors, and achieve the goal of studying "comprehension subject" the researcher suggests P.O.S.S.E strategy due to the following purpose: (1) POSSE Strategy consist of two pre-reading strategies: 
Predict and Organize $(\mathrm{P} \& \mathrm{O})$, and tow during reading strategy: Search, Summarize, (S\&S), and post-reading strategy: Evaluate (E). That means predict the main idea of each paragraph of text. Organize the ideas into a cognitive map. Search for structure, students search for main idea, vocabularies, structure ...etc. Summarize the main idea in once own words, Evaluate what have been predicted and compare it with the existed one.

\section{The Hypothesizes of the Study}

The study seeks to prove the following hypothesizes:

1- There are statistical significant differences at $(\alpha=$ 0.05 ) in the mean scores of the reading comprehension achievement of second grade EFL students that can be attributed to the teaching strategy.

2- Students can implement the POSSE Strategy Successfully.

\section{Significance of the Study}

The present study hopes to promote EFL students' reading comprehension Via implementing the steps of POSSE Strategy. The activities of POSSE Strategy correspond with the objectives of learning "Comprehension Subject" in the first and second grades at English department in the college of Education in the Iraqi Universities. The results of the present study may be useful as a model in teaching reading skill in English language. Also, it may consider as a method to solve reading comprehension problems.

\section{Aims Of The Study}

The present study aimed to improve EFL second grade University students reading comprehension.

\section{Limitations of the study}

1- The use of POSSE strategy to improve students' reading comprehension.

2- Location: The place of the college is in Baghdad at the university of Baghdad (College of Agriculture: The alternative place of the University of Anbar)

3- Time: the study was implemented in the second semester of the academic year 2016-2017.

4- Participants: The participants are from second grade EFL (Morning and Evening class) male and female students (They are enrolled in one class).

5- The duration: The duration of the experiment to took two months.

\section{Definition of the Basic Terms}

To avoid any ambiguity in the terminology used in this study, the researcher defined them theoretically and operationally as follows:

1- POSSE Strategy:

Theoretical Definition: Englert and Mariage (1991) present POSSE as reading comprehension strategy to comprehend information form any text. Posse stands for Predict, Organize, Search, Summarize, Evaluate. (Tiarina, and Arianti, 2014:197).

Operational Definition: POSSE refers to:

1- Predict: to activate students background knowledge by brainstorming what the theme will be about. To do so, the researcher uses the title, the picture(s) and sometimes read the first line of the first paragraph.

2- Organize: The students will use concept map to organize their predictions.

3- Search: The students will read the paragraphs of a given text to search for new vocabularies, main ideas for each paragraph, and the support ideas, and the structures.

4- Summarise: the students will use concept map through group discussion to identify the key idea of each paragraph.

5- Evaluate: The students will evaluate their understanding by comparing the two semantic maps which have been done in the prediction step and the one which completed after reading the paragraphs.

2- Reading Comprehension:

Theoretical Definition: Klingner et al. (2007:2) define reading comprehension as "The process of constructing meaning by coordinating a number of complex processes including word reading, word and world knowledge, and fluency".

Operational Definition: It is defined as the ability of the students to interpret the words, understand the meaning and the relationships between the ideas of the paragraphs.

3- EFL University Students: The EFL is stands for English as a foreign language. It means all the students who study English language as a specialize in a university (Floris, and Divina,2009:37)

Operational Definition: It means the second grade students at English department at college of Education for humanities.

\section{THEORETICAL FRAMEWORK}

\subsubsection{The Reading Process}

Reading means to be able to comprehend a written text, to understand the required information successfully (Grellet, 1981:3). The popular types of reading metaphors are bottom-up views, top-down views, and interaction (or integrative) views (Ferris 2009:16).

The aim of bottom-up is how learners "readers" construct meaning ful messages from structural elements of a text. Whereas, the goal of "Top-down" is to clarify how learners "readers" construct meaning by fetching previous knowledge to the act of reading, and how learners "readers" utilize multiple textual "cues" to understand text 
messages. The third view is the interactive (integrated) view which aims at explaining how bottom-up and topdown processes interact with and complement on another (Bernhardt, 2005:140).

\subsubsection{The Importance of context and Background} Knowledge in the comprehension Process

Many language learners encounter difficulties when trying to comprehend a spoken or written text in the target language, especially when one is in the advance stages of learning a target language (Hadley, 2001:144).

Beginning in the 1960s, the role of meaningful and organization of background knowledge was particularly emphasized by cognitive Psychologists. For material to be meaningful, it must be based on existing knowledge that learner already Possesses. This existing knowledge must be organize in such a method that the new information is easily attached to the learner's cognitive structure. Ausubel (1978) emphasises that teachers have to provide "advance organizers" (textual organizer) to facilitate the learning of new material (Ibid:144-145).

\subsubsection{Advance Organizer Compared to other Pre- reading Activities}

Many studies have investigated the effects of providing subjects with a title or topic for a passage before reading. The studies prove that presenting a title of a topic, or the topic in a brief sentence or two before reading has activated learners' knowledge, and promote comprehension of the passage (Schank and Abelson, 1997).

In addition, second language researchers have investigated the effect of summaries the main ideas of a passage. The summaries and questions are being used as advance organizers to examine their effects on college students comprehension (Herron, 1994)

\subsubsection{Types of Text}

A variety of definitions of text have been presented by linguists, reading theorists, and Specialists in text analysis. One general definition of text is "a verbal record of a communicative act" (Wallace, 1993:6). In addition, readers must grapple with multiple types of information encoded in text. These include (1) Orthograph (writing/spelling system). It can be divided into three categories: logographic [Chinese, Japanese], syllabic [Japanese kana, Korean hangul] , and alphabric [Arabic, English, Russian, Freek]. (2) Word [it is the most basic unit of a written text]. (3) morphosyntactice information. (4) Cohesive ties, and text structure. Textual information includes typographic information such as capitalization, punctuation, and paragraphing.

\subsubsection{Type of Reading Comprehension}

Brown (2001:312) mentions two types of reading comprehension. The first one includes silent and oral reading (to read aloud). The second one includes intensive and extensive reading. Readers use intensive reading when they focus on the linguistic details of the text; whereas, they use extensive reading when they are reading for pleasure. In the present paper, the researcher is concerned with intensive reading which help the students to comprehend the text in a meaningful way. The researcher believes that in order to implement intensive reading strategy, the teacher should follow three stages. The first is pre-reading activities. In this stage the teacher prepares the students to :

1- get ready to read (At least three distinct activity types can be included schema activation: (what do students already know about content, structure, and language of a given text); schema development, and establishing purpose for reading). (Hedgcock, and Ferris, 2009)

2- surveying the text.

3- Making prediction and ask question.

4- Introducing key vocabulary.

The second is during reading activity. In this stage, the teacher prepares the students for:

1- First reading: it is not part of the pre-reading stage, which refers to a quick read to a text to develop a sense of its main points and to predict its component. First reading means student are ready to read the text intensively.

2- Re-reading the text to monitor and ensure student comprehension.

3- Looking closely at language.

4- Considering the structure of the text. (Ibide 171176)

The third is post-reading activities in this stage, the teacher prepare the students for :

1- Summarizing and responding. It requires an understanding of the key ideas in a text and an ability to distinguish among main points and supporting details. It is considered as a good review and comprehension check tool.

2- Reading Writing Connections (comprehension questions, vocabularies review, and summarizing) (Ibid:188)

\subsection{P.O.S.S.E Strategy}

\subsubsection{Definitions of P.O.S.S.E Strategy}

The P.O.S.S.E strategy is developed by Carol Englert and Troy Mariage in 1991, it is a reading comprehension strategy. P.O.S.S.E Stands for Predict, Organize, Search, Summarize, and Evaluate. It encompass some reading comprehension techniques such as advance organizer, text structures, self-assessment, activates previous knowledge, encourages the learners to organize their knowledge, and compare between what they knew and what they have learned recently (Aprilia, 2015: 24) 
Freville and Collen (2006 cited in Aprilia, 2015) prove the notion of POSSE strategy, they say it is a multistep instructional strategy which helps learners to organize their knowledge and summarize and elaborate between what they knew and what they have learned.

Later, Westwood (2008: 45) states that "POSSE strategy is designed to activate learner's previous knowledge and to link it with new one".

Based on the characteristics of P.O.S.S.E Strategy, the researcher in this paper choose it to develop students' reading comprehension.

The P.O.S.S.E Strategy consists of three phases: Prereading, during reading, and post reading. The following are the characteristics and the steps of implementing the strategy.

1- Predict: the students guess what the topic talks about. The learners are forced to activate their previous knowledge. The teacher uses title, pictures, some lines from the text. (Klinger, et at, 2007)

2- Organize: the learners organize, arrange, the ideas which they have predicted in "Semantic (concept) Map". The teacher discusses with learners what new ideas they have predict (Bergerson: 2001cited in Aprilia:2015: 26)

3- Search: the learner begins reading the topic silently and searches for the main idea of each paragraph, and the new vocabularies that they do not know their meaning. This step confirms learners' predictions by comparing them with the new ideas and vocabularies they found during reading the text (Aprilia, 2009:26)

4- Summarize: Students identify the main idea of each paragraph, then join them to form an acceptable summary of the whole text.

5- Evaluate: The learners do four things in this step, they ask questions, compare between the information they have predicted (in the POSSE sheet) with the new one they have founded, (in the POSSE sheet), then they clarify about new information from the teacher for unknown information or unclear vocabularies, or unfamiliar things (Klinger et at, 2007).

6- At the end, the learner summaries the reading text by reviewing P.O.S.S.E strategy sheet (Appendix 1).

\subsubsection{The Merit of P.O.S.S.E Strategy}

The founder of POSSE strategy Englert and Marriage (1991) and Brownell (2012:116) State the following merit and advantages of using POSSE strategy in developing reading comprehension for the EFL learners as follow:
1- The learners have the opportunity to activate their previous knowledge and connect it with a specific topic to predict new information.

2- The learners have the opportunity to practice the experience of using advance organizer in learning new information of a foreign language.

3- The learners can infer a new topic by utilizing their background knowledge.

4- The learners have the opportunity to share information with whole group.

5- The learners have the opportunity to monitor, and evaluate themselves by comparing their knowledge before acquiring the new information and after the instructional process. The students (in groups) compare the first graphic organizer (done in prediction step) and the second one (done in search step).

6- The learners have the opportunity to learn how to summarize a text successfully, without missing necessary information. This activity develops learner's comprehension of the new information, and enlarge the vocabularies bank.

Tiarina, and Arianti (2014) found that it is necessary for the teacher who uses POSSE Strategy to arrange the students in groups, distributes POSSE sheet then explain the purpose and basic competencies of the strategy from very beginning.

They also prove that POSSE strategy is the most appropriate strategy to teach reading analytical exposition, because it is a kind of expository text, it covers all reading activities: Pre-reading, during reading, and Post-reading.

Pesa and Somers (2007) found that the $7^{\text {th }}$ and $8^{\text {th }}$ grade students have Skip 'predict' step. This lead to not be able to identify the main idea of the text, because the teacher did not take time to explain it, and the students did not have time to be familiar with the text before reading it, thus they skip this step. So, it is important to explain several times the procedures of using POSSE Strategy even if it takes several meeting.

\subsection{Review of related literature}

The following are empirical studies which investigated the effectiveness of using P.O.S.S.E Strategy in improving and developing students' reading comprehension.

Pesa and Somers (2007) conduct a study to investigate the effect of POSSE Strategy on $7^{\text {th }}$ and $8^{\text {th }}$ Chicago Middle School. The participants of the study were expose to reading comprehension strategies, one of them was POSSE Strategy. Pre and Post text were used to collect the data of the study. The results revealed that students do not use all steps of the strategy. This lead to only $21 \%$ of the students being able to comprehend the text. 
Meljulita (2012) investigates the effect of POSSE Strategy in improving reading comprehension of the $8^{\text {th }}$ grade students of SMP N2 Jujuhan. Pre-Post tests were used to collect the data of the study. The findings reveal that the strategy has improve students' reading comprehension.

Yunetri (2014) investigates the effect of POSSE and Picture walk strategies on improving students' reading comprehension. The participants were from senior high school. Pre-and post test were used to collect the data of study. The findings reveal that POSSE strategy activates students' reading abilities.

Aprilia (2015) investigates the effect of POSSE strategy on improving students reading comprehension. The participants were from eighth grade. Pre and post test were used to collect the data of the study. The findings reveal that the strategy has allowed the learners to predict the text, organize the prediction, searching the man idea, maximizing their vocabularies, successfully. The learners become independent learners in comprehending text.

Arianti and Tiarina (2014) investigate the effect of POSSE Strategy on developing students reading analytical exposition text. The participant were from senior high school students. pre-post test were used to collect the data of the study. The findings reveal that the strategy has activated students background knowledge, and it helps learners to comprehend the text easily.

\subsection{Participants of the study}

\section{RESEARCH METHODS}

The participants were chosen purposefully, because the researcher conducted an action research on the second grade at English department at the college of education for humanities-university of Anbar for the second semester of the academic year 2016-2017. The total number of the participant is 69 Table 1 shows the distribution of the participants.

Table.1: Distribution of the Participants

\begin{tabular}{|l|l|l|l|}
\hline Class & Males & Females & Total \\
\hline Morning & 17 & 28 & 45 \\
\hline Evening & 13 & 11 & 24 \\
\hline Total & 30 & 39 & 69 \\
\hline
\end{tabular}

\subsection{Variables of the study.}

1- The independent variable is the instructional instrument of the study, the P.O.S.S.E Strategy.

2-The dependent variable is the students reading achievement scores on the posttest.

\subsection{Research Instrument}

The researcher use observation check list, and pre and Post test (reading comprehension tests) to collect the quantitative and qualitative data of the study. The data of the study were in the form of field observation.

\subsubsection{The Pre-Post Test}

The pre-post test request from students to:

1 - Identify the main idea.

2- Find the purpose of the text (the story).

3 - Find the supported ideas of the main ideas.

4- Guess the meaning of unfamiliar vocabulary .

5 - Find references.

6- Identify the sentence that summarize the text.

\subsubsection{Test Validity}

The Pre and Post-test have exposed to the English language instructors specialists in methodology as jury members in order to ensure the face validity of the tests. The jury made some amendments and provides recommendations.

\subsubsection{Pilot of the study}

The Pre-and post test were given to 8 girls from second grade at English department at the college for women in the University of Anbar. It is found that the length time needed for each test is 60 minutes, and the instructions of the tests are clear.

\subsection{The Reliability of the Tests}

The reliability was obtained by using test-retest method. Within 10 days period. The re-test reliability was computed by using person correlation between the two tests. The internal consistency reliability value was 0.91 and the value of the stability index was 0.86 .

\subsection{The Observation checklist}

The researcher design an observation checklist (Appendex2) to meet the aim of implementing POSSE Strategy in improving reading comprehension. The checklist divided into three domains. The first domain checks students' pre-reading activities (predict, and organize).The second domain checks students' during reading activities (Search and summarize). The third domain checks post-reading activity (Evaluate).

\subsubsection{Validity and Reliability of the Observation} Checklist

The validity was obtained by specialists in methodology in Baghdad, and Al-Mustansiriah University. Modifications have been made according to their suggestions.

To prove the reliability of the observation checklist, the triangulations (Time, investigator, and theoretical) proposed by Burns (1999:164) were used as follows:

1- Time triangulation: The observations were done in the second semester 2016-2017.

2- Investigator triangulation: There were two observers who check students' performances to avoid the bias. 
3- Theoretical triangulation: The data were analyzed by the researcher, and two instructors from educational and psychological department who specialized in educational statistics.

\subsection{Type of Research}

The present study is an action research. Class-room action research is a research conducted by teachers inside the classroom. The teacher plans, implements, and reflects the action (Treatment strategy) to improve or develop a performance or a skill (Kusumah, and Dwitagama, 2012:9).

The researcher asked two of his colleagues to observe students' actions. The ideal classroom action research is one that is carried out in pairs between the ones who perform the action and at least one who observe the ongoing proses of implementation of the action (Ibid:9).

The researcher adopts Kemmis and Mctaggart model (2010:9) the model consists of eight steps as follows:

Phase 1: Planning, first action, first observation, first reflection

Phase 2: $\quad$ revision against first planning, second action, second observation, and second reflection.

\subsection{Research Procedures}

The research is divided into two phases: the first phase is divided into four phases: planning, action, observation, and reflection as described below:

\section{First: Planning Phase}

The researcher sets the lesson plan for each meeting to implement the P.O.S.S.E Strategy. Also, the researcher discusses the plan with the observers. The time of the experiment has been set.

\section{Second: Action Phase}

The researcher teaches the reading skill via P.O.S.S.E Strategy. The texts were the same texts in the "Comprehension Textbook" for second grade. The action has implemented in five steps based on the steps of P.O.S.S.E Strategy (Predicting, Organizing, Searching, Summarizing, and Evaluating).

The first action was "Predict". The researcher used brainstorming activity to activate students' background knowledge, by using cues from the text such as the title, headings, pictures, and some lines from the paragraphs in order to predict what the story might be (by predicting many ideas related to the topic), and mentioning vocabularies based on their background. The researcher explained to the students how and what they must do in the POSSE Sheet.

The teacher may ask the following question in the prediction step" what do you think this text is going to be about?"

The second action was "Organizing". The researcher asked the learners to organize their ideas which they have predicted in the first phase in categories as mentioned in the POSSE sheet. The categorization would be based on the generic structure of the text. The students organized their new ideas (which they have predicted) into semantic map. (POSSE sheet). This action needs the guide of the teacher especially on the first and the second meetings.

The third action was "Searching". Students read the text silently to identify the main idea of each paragraph, and search for new vocabularies, and unfamiliar information and then write them on POSSE sheet.

The fourth action was "Summarizing". The students summarized the text based on the "advance organizer" presented in the POSSE Sheet. The students used the main ideas of each paragraph which have been written during the third action (Searching) and joined them to form a suitable summary. This step enabled students to understand the text in general.

The fifth action was "Evaluating". It is the final phase which consisted of four processes:

1- Question: the students answered comprehension questions based on the summary of the text, and wrote the answers on the POSSE Sheet.

2- Compare: The students compared between the two semantic Maps, the one they have written in the "prediction" action, and the one which done on the "search" action, to enrich their vocabularies and information.

3- Clarify (is an optional action): The students asked about the unfamiliar vocabularies, unclear information or event which not clear in the text. The text may need cultural background, and this is done by the guide of the teacher.

Finally, the students submitted the POSSE Sheet to the teacher (researcher)

\section{Third: Observation Phase}

In this phase, the observers use observation check list (Appendix 2) to observe students reading process, and the problems they may face during the implementation of each phase, and also to record the action of the lesson. After checking the lessons (Meeting), the researcher evaluates the observation checklists to check to what extent does the POSSE strategy improve students' reading comprehension, and analyzes the obstacles and the weakness points, and to find what students need more to use the strategy effectively to improve their reading comprehension.

\section{Fourth: Reflection Phase}

In this phase, the researcher reflects, evaluates and provides explanation of the impact of POSSE Strategy on the learners' reading comprehension.

The researcher gathers students' POSSE Sheets, and the observation check lists to analyze them.

3.8. Step for Applying the POSSE Strategy 
The researcher followed the three main teaching reading activities: Pre-reading, during reading, and Post reading to implement the POSSE strategy.

1- The Pre-reading activities include 'predict', and 'Organize'. The researcher showed the students a picture existed within the text-book, in addition, the researcher downloaded some pictures from the internet related to the topic, then read the title of the text, and asked students to write (in the POSSE Sheet) what they predict the topic might be. Then, the students organized their ideas in categories, and wrote them in the POSSE Sheet such as: "I think one Calgary might be...."

2- The during-reading activities includes "search" and "summarize" actions. Students begin to read (in groups) silently to search for the main idea of each paragraph, and find the new vocabularies. They write them down in the POSSE Sheet. They may write : "I think the main Idea is ...." Then, they join the main ideas with conjunctions to form a summary for the text.

3- The post-reading activities include 'Evaluate' action, the students do the following:

(1) Students wrote, in the POSSE Sheet, the new vocabularies.

Table.2: Means and standard deviations of the students scores on the pretest and posttest due to teaching strategy, and the adjusted means and standard errors of the posttest.

\begin{tabular}{|c|c|c||cc|c|c||}
\hline \multicolumn{3}{|c||}{ Pre-test } & \multicolumn{4}{c||}{ Posttest } \\
\hline \hline No. & Mean & Std.Dev & Mean & Std.Dev. & Adj.Mean & Std.Error \\
\hline 69 & 6.12 & 1.34 & 9.82 & 0.87 & 13.72 & .24 \\
\hline
\end{tabular}

Tables 2 reveals an observed differences between the two means of the students scores on the Pre-and Posttests due to the teaching Strategy. To investigate the significance of the observed differences, ANCOVA was used Table (3) presents the results of this analysis.

Table.3: Results of ANCOVA of the students' scores on the Posttest.

\begin{tabular}{|c|c|c|c|c|c|c|}
\hline Source & $\begin{array}{l}\text { Sum of } \\
\text { squares }\end{array}$ & Df & $\begin{array}{l}\text { Mean } \\
\text { square }\end{array}$ & $\mathrm{F}$ & Sig & $\begin{array}{c}\text { Partial } \\
\text { Squared }\end{array}$ \\
\hline Posttest & 7.21 & 1 & 7.21 & 49.25 & 0.000 & 0.13 \\
\hline POSSE Strategy & 41.38 & 1 & 41.38 & 247.69 & 0.000 & 0.85 \\
\hline Error & 13.39 & 91 & 0.144 & & & \\
\hline Total & 61.98 & 93 & & & & \\
\hline
\end{tabular}

To prove the second hypothesis "students can implement the POSSE strategy successfully". The researcher analyzed the observation checklists for students' performances as shown below:

The first meeting: (2 lessons: one topic) All students in the 'predict' step face some difficult in predicting vocabularies related to the topic, because it was the first time they use the strategy. When the researcher started to ask questions about the pictures and the title, few students began to reply with hesitation. No one predicted the
Table (3) reveals that there is a significant differences at ( $\alpha=0.05$ ) between the two means of the participants at the posttest due to teaching strategy in favor of the students after implementing the POSSE Strategy. the practical significance of the teaching strategy is $(0.85)$, that means $85 \%$ of the variance in the students' performance at the posttest is due to POSSE Strategy.

Results Related to the second hypothesis 
The researcher concluded that POSSE strategy has improve students reading comprehension, and it has save students' time and efforts.

\section{CONCLUSION OF THE STUDY}

The findings of the study consist of qualitative and quantitative data. The following part is the qualitative data analysis.

The study was done in two phases. The first phases consisted of three meeting, while the second phase consisted of two meetings. Each phase consist of planning, action and observation, reflection, and summary of the phase (To analyze the successful and unsuccessful action of the students and the teacher).

The POSSE strategy has enriched students' vocabularies, and enhance their participation inside the classroom, in spite the huge number in the class. The strategy increased the interaction of the teacher with all students, this happened when the researcher (instructor) provided guidance and assistance to the students in groups.

The observation checklists reveal some technique points related to teaching reading skills inside the classroom, that the teacher must manage the time, in order to implement the activities in good manner, also the teacher should provide students from very beginning, clear explanation to the strategy and the activities even if such thing takes one or two lessons, in order to save time and ensure that the students will apply the strategy well.

In the first and the second POSSE sheets, all the groups failed to do them because they still did not master the strategy, and most of them failed to fulfill the POSSE steps.

In the second meeting, the students were doing better in the predict, search, and summarize steps, while still face difficulty in organize, and evaluate steps. The researcher provided more examples and explanation to enable students to do these two steps. In the third meeting, after three weeks, the students showed high control of using the POSSE sheet. Their prediction became more reasonable, their vocabularies have been increased, and they can predict the story of the topic easily (usually their predictions were correct). Also, students helped each others to organize the idea on the POSSE sheet.

Concerning the summarize step, students showed high control to write a summary of the topic in smooth way. Finally, they can guess the meaning of some vocabularies, and find the others on the dictionary. The students answers the comprehension questions easily.

The findings of the qualitative data can be summarized in the following comparative table: theme by him/herself without the help from the researcher (instructor).

Concerning the "Organize" step, all students do not know how to write their idea in the POSSE sheet. The researcher write an example on the white board, and the students (in group) imitate the example.

Concerning the "Search" step, some students (in each group) did not read the text, while the other read it, thus not all students write the new vocabularies, and the main idea of each paragraph. When the researcher checked the groups, he asked the students (who did not participate in the action) about the reason behind not doing the action. Their answers were: "they do not understand how to use POSSE strategy", and some of them were depended on the group members to achieve the action.

The researcher did one example on the white board and then asked all groups to re-read the text again and to write (in the POSSE sheet) the new vocabularies and the main idea of each paragraph.

Concerning the "Summarize" step, all students (in each group) asked for the help of the researcher in order to write the Summary.

Concerning the "Evaluate" step, the students write the new vocabularies and ask the researchers about the meaning without using the dictionary or trying to guess the meaning.

In each group, one student can answer the comprehension question, while the rest cannot do. Concerning the comparison between the first POSSE sheet and the second one, all groups failed to do it, because they still did not master the strategy, and most of them failed to fulfill the POSSE steps.

In the second meeting, the students were doing better in the predict, search, and summarize steps, while still face difficulty in Organize, and evaluate steps. The researcher provided more examples and presented details and explanations to enable students to do these two steps. In the third meeting, after three weeks, the students showed high control of using the POSSE strategy, and fulfill the POSSE sheet. Their prediction become more reasonable, their vocabularies have been increased, and they can predict the story of the topic easily, in spite whether their prediction was correct or not, but usually their predictions were correct. Students helped each others to organize the idea on the POSSE Sheet. Concerning the summarize step, students showed high control to write a summary of the topic in smooth way. Finally, they can guess the meaning of some vocabularies, and find others on the dictionary. The students answers the comprehension questions easily, they derived the answers from the "search" step, and the "summary" step on the POSSE Sheets. 


\begin{tabular}{|l|l|l|l|}
\hline \multirow{2}{*}{ No. } & \multicolumn{1}{|c|}{ Pre-Treatment } & \multicolumn{1}{|c|}{ During and Post Treatment } \\
\cline { 3 - 5 } & $\begin{array}{l}\text { The learners knew some } \\
\text { vocabularies in general. }\end{array}$ & $\begin{array}{l}\text { Phe learners start to increase their } \\
\text { vocabularies, but still in low level. }\end{array}$ & $\begin{array}{l}\text { The learners enrich their vocabularies } \\
\text { and be able to guess the meaning of } \\
\text { unfamiliar words. }\end{array}$ \\
\hline 2. & $\begin{array}{l}\text { The learners encounter obstacles in } \\
\text { understanding the theme. }\end{array}$ & $\begin{array}{l}\text { The learners begin to comprehend } \\
\text { the theme via using POSSE } \\
\text { strategy. }\end{array}$ & $\begin{array}{l}\text { The learners can comprehend the } \\
\text { theme via using POSSE strategy. }\end{array}$ \\
\hline 3. & $\begin{array}{l}\text { The learners learn individually. } \\
\text { There is interaction between the } \\
\text { learners in groups. }\end{array}$ & $\begin{array}{l}\text { The learners share ideas and exchange } \\
\text { information, and even the lazy } \\
\text { students has a role to participate in } \\
\text { the activities. }\end{array}$ \\
\hline 4. & $\begin{array}{l}\text { Most learners were unable to answer } \\
\text { a comprehension question or give a } \\
\text { meaning of a word. }\end{array}$ & $\begin{array}{l}\text { Some learners be able to answer } \\
\text { comprehension questions via using } \\
\text { the information in the 'search' and } \\
\text { summary' steps. }\end{array}$ & $\begin{array}{l}\text { All } \\
\text { comprehension questions, and can } \\
\text { provide summary of the text } \\
\text { successfully. }\end{array}$ \\
\hline
\end{tabular}

The researcher concluded that POSSE Strategy has improved students' reading comprehension, and it has save time and efforts.

The quantitative data were obtained from the pre-and posttests students' reading comprehension scores. The Post-test results reveal that there is significant difference in the Post-test mean scores due to the teaching strategy. This result are consisted with the results of Pesa and Somers (2007), Meljulita (2012), Arianti and Tiarina (2014), Ynetri (2014), and Aprilia (2015).

Based on the results of the study, the researcher recommends to investigate the effect of POSSE strategy on students at the level of schools, and measure its effectiveness by making a comparison between control and experimental groups.

\section{REFERENCES}

[1] Aebersold, J., and Field, M. (1997). From Reader to Reading Teacher: Issues and Strategies for Second Language Classrooms. Cambridge, England: Cambridge University Press.

[2] Aprilia, N. (2015). Improving Reading Comprehension of the Eighth Grade Students at SMP N 6 Yogyakarta Through POSSE Strategy in the Academic Year of 2014/ 2015.

[3] Arianti, G., and Tiarina, Y. (2014). Teaching Reading Analytical Exposition text to Senior High School Students by using POSSE Strategy. UELT Journal, 3 (1): 196-201

[4] Bernhardt, E. (1991). Reading Development in a Second Language: Theoretical, Empirical, and Classroom Perspectives. Norwood, NJ: Ablex.

[5] Bernhardt, E. (2005). Progress and Procrastination in Second Language Reading. Annual Review of Applied Linguistics, 25, 133-150.
[6] Brown, D. (2001). Teaching by Principles: An Interactive Approach to Language Pedagogy Second Edition. San Francisco: Addison Wesley Longman, Inc.

[7] Floris, F., and Divina, M. (2009:37). A study on the Reading Skills of EFL University Students. TEFLIN Journal, 20 (4)::37-47

[8] Grellet, F. (1981). Developing Reading Skills. Cambridge, England: Cambridge University Press.

[9] Hadley, A: (2001). Teaching Language in Context. Heinle and Heinle, Thomson learning, Inc

[10]Hedgcock, J., and Ferris, D. (2009).Teaching Reading of English. Routledge, Taylor and Francis.

[11]Herron, C.(1994). An investigation of the Effectiveness of using an Advance Organizer to Introduce Video in the foreign language classroom. The Modern language Journal 78 (11): 190-98.

[12]Hudson, T. (2007). Teaching Second Language Reading. Oxford, England: Oxford University Press.

[13]Ferris, D. (2009). Multiple Student Audiences in L2 Writing Instruction. Ann Arbor: University of Michigan Press.

[14] Klingner, J. Vaughn, S., and Boardman, A. (2007). Teaching Reading Comprehension to Students With Learning Difficulties. New York: The Guilford Press.

[15] Kusumah, W., and Dwitagama, D. (2012). Mengenal Penelitian Tindakan Kelas. Jakarta: PT Indeks.

[16] Pesa, N., and Somers, S. (2007). Improving Reading Comprehension Through Application and Transfer of Reading Strategies. Published thesis Saint Xavier University and Pearson Achievement Solutions, Chicago, Illinois.

[17] Schank , R; and Abelson, R. (1977). Scripls, Plans, Goals, and understanding: An Inquiry into Human 
Knowledge structures. Hillsdale, NJ: Lawrence

Eribaum Associates.

[18] Tiarina, Y.; and Arianti, G. (2014:197). Teaching Reading Analytical Exposition Text to Senior High School Students By Using POSSE (Predict, Organize, Search, Summarize, Evaluate) Strategy .JELT journal, Vol 3 (1) C.

[19] Wallace, C. (1993). Reading. Oxford, Oxford University Press.
[20] Westwood, P. (2008). What Teachers Need To Know About Reading and Writing Difficulties. Victoria: ACER press.

[21] Yunetri, S. (2014). Teaching Reading Narrative Text by combining Picture walk and POSSE Strategies for senior High School. Pendidikan Bahasa Inggris Vol. 1C1).

Predict: What Ideas are in the text.

POSSE Sheet (Form)

Organize: Organize your thought (use your ideas from above and then organize them into this concept map)

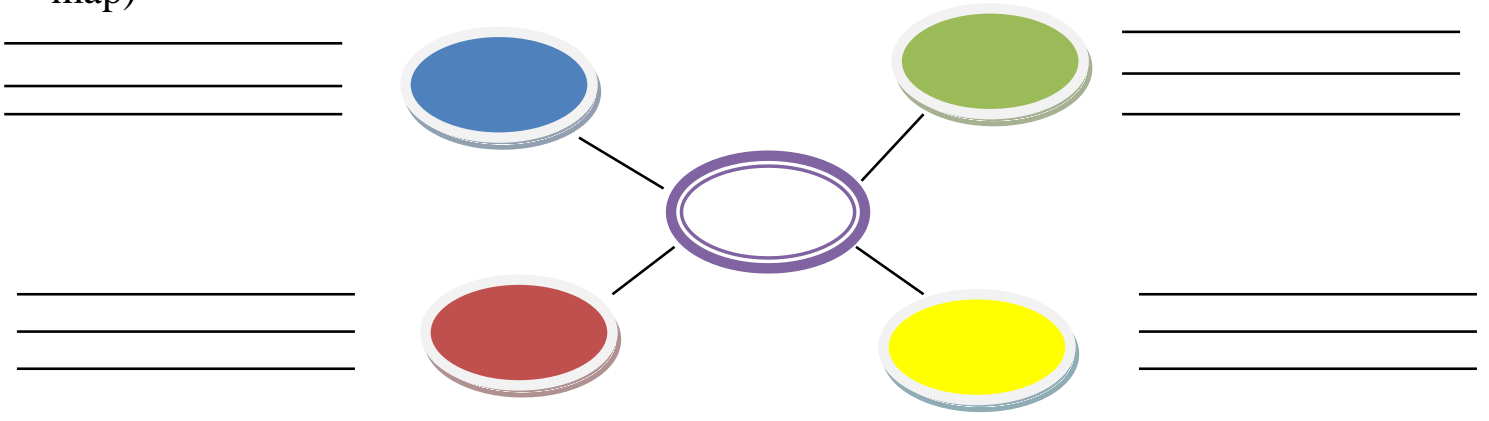

Search: Search for the main idea and confirmation of your predictions (after reading the text complete the main ideas advance organizer)

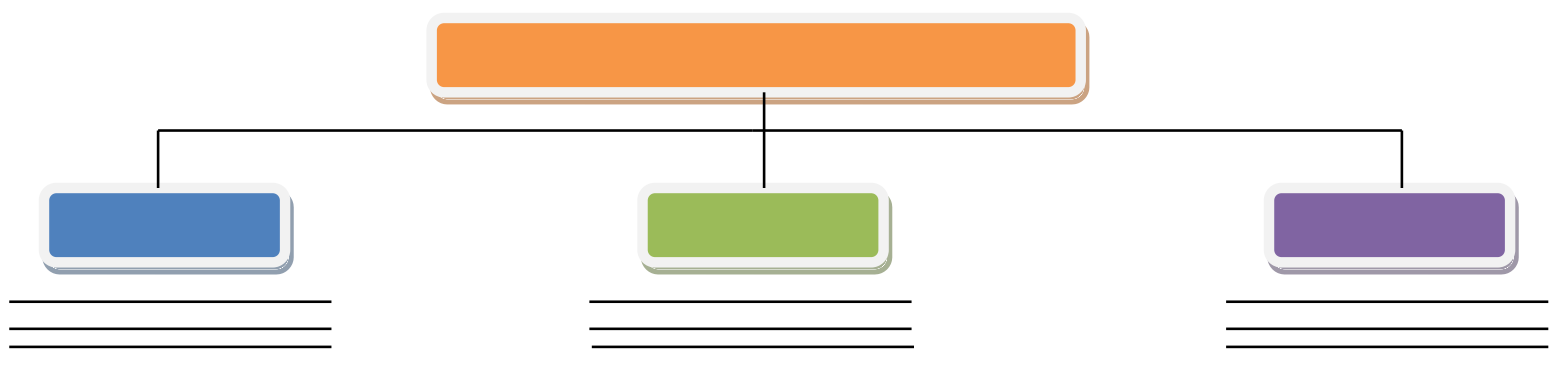

Summarize: Summarize the main idea in 1 or 2 sentences.

Main idea sentences or comprehension questions and answers

Evaluate: Compare maps- clarify any new words- predict what you will read about next.

Predict I predict that . . I'm remembering ... Search/Summarise I think the main idea is . . My question about the main idea is 'What if...' Evaluate 'Compare the ideas in this map... with the after reading concept map or organiser...' Are there any further explanations of new words needed? I predict the next part will be about ... 
Predict: I predict that ...

Search/Summarise: I think the main idea is ...

My question about the main idea is 'What ...'

Evaluate: 'Compare the ideas in this map...with the after reading concept map or organiser...'

Are there any further explanations of new words needed?

I predict the next part will be about...

\section{Appendix 2}

\section{Observation Checklist}

Date:.............. Meeting: ............... No. of Observing:

\begin{tabular}{|c|c|c|c|c|c|}
\hline No. & & Reading Action & Yes & No & Observer's notes \\
\hline $\mathbf{i}$ & & Pre-Reading & & & \\
\hline $1-$ & \multirow{4}{*}{$\stackrel{0}{0}$} & $\begin{array}{l}\text { The researcher demonstrates the form of P.O.S.S.E } \\
\text { STRATEGY and explains the procedures of the lesson. }\end{array}$ & & & \\
\hline $2-$ & & $\begin{array}{l}\text { The students suggest vocabularies and idioms related to } \\
\text { the subject. }\end{array}$ & & & \\
\hline 3- & & $\begin{array}{l}\text { The researcher asks some question about the title and } \\
\text { picture(s) of the subject. }\end{array}$ & & & \\
\hline $4-$ & & The learners predict the theme. & & & \\
\hline $5-$ & \multirow{2}{*}{. } & The students write down their ideas in a sheet of paper. & & & \\
\hline 6- & & The students organize the ideas in the POSSE Form. & & & \\
\hline ii & & During Reading & & & \\
\hline $7-$ & \multirow{3}{*}{ 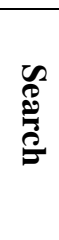 } & The students read the paragraphs (in groups) silently. & & & \\
\hline $8-$ & & Each student writes down the difficult words. & & & \\
\hline 9- & & $\begin{array}{l}\text { The students discuss in group then write the main idea of } \\
\text { each paragraph. }\end{array}$ & & & \\
\hline $10-$ & \multirow{2}{*}{ 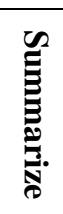 } & $\begin{array}{l}\text { The students in groups ask the help of the researcher to } \\
\text { write the summary. }\end{array}$ & & & \\
\hline $11-$ & & The students (in group) summarize the subject. & & & \\
\hline iii & \multirow{5}{*}{ 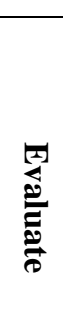 } & Post reading & & & \\
\hline $12-$ & & The students write the new words & & & \\
\hline $13-$ & & The students search the meaning of the new words. & & & \\
\hline $14-$ & & Each group presents its PSSE sheet. & & & \\
\hline $15-$ & & The students (in group) answer the comprehension. & & & \\
\hline
\end{tabular}

